\title{
Dynamics of employment assimilation
}

Alpaslan Akay ${ }^{1,2,3}$

Correspondence:

alpaslan.akay@economics.gu.se

'University of Gothenburg,

Vasagatan 1, Box 640, 40530

Gothenburg, Sweden

${ }^{2}$ IZA, Bonn, Germany

Full list of author information is

available at the end of the article
Springer Open

\begin{abstract}
This paper investigates the dynamics of immigrants' employment assimilation in comparison with the standard static assimilation model. When the effect of past employment experience on current employment possibilities differs between immigrants and natives, then the static assimilation model might produce biased and unrealistic predictions of the relative employment probabilities of immigrants. Using a high-quality panel dataset collected in Sweden and a state-of-the-art non-linear dynamic assimilation model, we find a large employment status persistence that substantially differs between immigrants and native Swedes. We show that failing to control for the differential past labor market experience leads to an incorrect account of the host country-specific human capital that results to a large overestimation (underestimation) of the short-run (long-run) marginal assimilation rates when using the standard static assimilation model.
\end{abstract}

JEL Classification: C33, J15, J61

Keywords: Dynamic panel data models, Employment assimilation, Initial values problem

\section{Introduction}

One policy target of highly immigrated Western countries is to assimilate the existing immigrant stock into the labor market as quickly as possible. Thus, the key measure that will inform the policy makers is the labor market performance of immigrants relative to that of the native population. Previous studies on Western countries suggest that not only is the growth of immigrants' relative outcomes weak, but their outcomes also quickly diverge away from that of natives and the outcomes also differ by region of birth, arrival cohort, and education (e.g., for North America, see Chiswick 1978; Borjas 1985, 1987; LaLonde and Topel 1991, 1992; Baker and Benjamin 1994; Dustmann 1994; and Duleep and Regets 1999; for Europe, see Aguilar and Gustafsson 1991; Gustafsson and Zheng 2006; Bauer et al. 2000; Bell 1997; Hayfron 1998; Longva and Raaum 2002; Barth et al. 2004; Bevelander 1995, 2005; and Hammarstedt 2001, 2003). The labor market success of immigrants in the host country requires a continuous accumulation of host countryspecific human capital, skills, and experience (e.g., learning the language, getting information about the channels to find a job, and knowledge about the local culture) after arrival, with which the immigrants can compete with natives (Chiswick 1978; Borjas 1985). Immigrants, however, confront several difficulties in obtaining host country-specific skills and experience since they are vulnerable to disadvantages that may lead to various patterns of interruptions or discontinuities in their employment status and human capital accumulation process compared with natives (e.g., Chiswick et al. 1997; Constant and

(c) 2016 Akay. Open Access This article is distributed under the terms of the Creative Commons Attribution 4.0 International License (http://creativecommons.org/licenses/by/4.0/), which permits unrestricted use, distribution, and reproduction in any medium, provided you give appropriate credit to the original author(s) and the source, provide a link to the Creative Commons license, and indicate if changes were made. 
Massey 2005; Frijters et al. 2005). The aim of the present paper is to incorporate the differential past labor market experience of immigrants and natives into the standard assimilation models to investigate the dynamics of employment assimilation among immigrants in the Swedish labor market.

The assimilation of immigrants is typically analyzed using either a cross section of individuals or panel datasets in a static modeling framework (e.g., Chiswick 1978; Borjas 1985, 1995; Aguilar and Gustafsson 1991; Hayfron 1998; Husted et al. 2001; Barth et al. 2004; Bevelander 1995, 2005). The standard static approach (with or without panel dataset) used in the previous literature is limited as it cannot account for effect of past employment or unemployment experiences on current or future employment outcomes. On the one hand, a structural state dependence on employment status might be present due to actual past employment experiences. On the other, a spurious state dependence, which can alter employment propensities independently from actual employment experience, might be present simultaneously due to time-persistent unobserved individual characteristics (e.g., personality characteristics, motivation, or ability). The employment status persistence of immigrants and natives is expected to differ as their unobserved characteristics and the labor market conditions they face differ (Borjas 1985). When the effect of past employment experience on the current employment possibilities differ between immigrants and natives, the static assimilation model might produce biased assimilation predictions.

There are several factors that can lead to differing patterns of labor market experience over time for immigrants and natives. First of all, immigrants' human capital acquired in their home country may not be perfectly transferable (Friedberg 2000). Second, failure to find a job for an immigrant upon arrival may "scar" future job possibilities (Chiswick et al. 1997; Husted et al. 2001; Åslund and Rooth 2007). Third, employers may perceive an unemployment experience in the past as a "signal" of low productivity (Hyslop 1999). They may also judge immigrants and natives differently even if they have the same labor market experience, i.e., labor market discrimination (Constant and Massey 2005). Finally, immigrants typically lack language skills and have less information about the host country labor market, leading to less effective job search methods with a higher cost (Frijters et al. 2005). ${ }^{1}$ Thus, immigrants experience several disadvantages that might lead to more frequent employment status transitions and interruptions in their human capital accumulation process in comparison with natives. To account for the differential past employment experience between immigrants and natives, we estimate the relative employment outcomes of immigrants using a nonlinear dynamic panel data assimilation model in which we explicitly control for past employment experiences of immigrants and natives.

This paper focuses on the relative employment outcomes of immigrants in the Swedish labor market. The Swedish population has a higher proportion of immigrants (14 \%) than most other countries in the world. Several studies have used the static framework to investigate the relative labor market outcomes of immigrants (i.e., both earnings and employment) of immigrants in Sweden. Almost all studies on immigrants in Sweden report a weak assimilation process (e.g., Aguilar and Gustafsson 1991; Ekberg 1994; Scott 1999; Bevelander 1995; 2005; Edin et al. 2000; Hammarstedt 2001, 2003; Duvender 2001; Gustafsson and Zheng 2006; Asslund and Rooth 2007). We are going to estimate the standard static model 
similar to the one used in the existing studies and compare the results with those of the dynamic assimilation model. One of the other advantages of focusing on the Swedish labor market is that Sweden offers a high-quality national administrative panel dataset with a very low attrition and measurement error: the Longitudinal Individual Dataset-LINDA. The dataset covers the entire Swedish population allowing greater flexibility in selecting representative samples. In order to focus on the research question extensively, we focus mainly on male immigrants. In our empirical analysis, we include half a million observations of immigrant men and an equal number of native Swedish men, who are randomly selected from the national population register.

Our main results can be summarized as follows. First of all, there is a strong and positive structural state dependence on the employment status of both native Swede and immigrant men. Second, the dependence of the current employment probability on past experiences largely differs between natives and immigrants. Natives experience a substantially higher employment status persistence than immigrants. Third, the immigrant population is highly heterogeneous with respect to employment status persistence. We split immigrants into seven regions of origin. The immigrants from Western countries and Eastern Europe experience a relatively higher employment status persistence. Finally, the predicted assimilation outcomes differ remarkably between the static and the dynamic model, especially when the magnitude of state dependence of natives and immigrants are largely different. The static assimilation model predicts very high marginal assimilation rates in the initial years after arrival, but in fact, the rates are quickly turned to negative, as employment probabilities of immigrants unrealistically diverge away from those of native Swedes. Controlling for the differential past labor market experience has a substantial effect on assimilation outcomes. It lowers both the unrealistically high speed of assimilation and the depreciation rates of human capital as the number of years-since-migration increases. The dynamic model fits the data well and predicts that there is a slow yet steady accumulation of Swedish labor marketspecific human capital, and once acquired, immigrants are able to keep their human capital at the same level for longer periods with lower depreciation rates. In summary, the dynamic model predicts a lower initial employment probability advantage (10-15 percentage points) upon arrival yet longer years of positive marginal assimilation rates (up to 5-15 years), compared with the predictions of the static assimilation model.

The remaining part of the paper is organized as follows. Section 2 discusses the dynamic assimilation model, in which we control for past employment status and unobserved individual effects. Section 3 presents the data, our sample selection, descriptive statistics, and the raw employment transition patterns of natives and immigrants. Section 4 gives the results from the static and dynamic assimilation models split by regions of origin and education levels. Section 5 summarizes the results and draws conclusions.

\section{Econometric specifications}

\subsection{The dynamic assimilation model}

In order to investigate the effect of differential employment status persistence on the relative employment outcomes, we specify a dynamic random-effects probit model for both immigrants and native Swedes. The assimilation model explicitly controls for the 
past employment status, several observed and unobserved individual characteristics, and endogenous initial values. The dynamic employment-generating process of immigrants $(I)$ is specified as follows:

$$
\begin{aligned}
& d_{i t}^{I}=1\left(x_{i t}^{\prime} I \beta^{I}+\lambda^{I} d_{i, t-1}^{I}+\varphi^{I} a g e_{i t}^{I}+\phi y s m_{i t}+\sum_{j} \psi_{j} C_{j}+\sum_{k} \theta_{k}^{I} \Pi_{k}^{I}+u_{i t}^{I}>0\right) \\
& u_{i t}^{I}=\eta_{i}^{I}+\varepsilon_{i t}^{I}, \\
& d_{i 1}^{I}=1\left(z_{i 1}^{\prime} I \beta_{1}^{I}+u_{i 1}^{I}>0\right),
\end{aligned}
$$

where $d_{i t}$ is a binary dependent variable indicating whether an immigrant is employed in the current period $t$ ( $i$ denotes the individual, $i=1, \ldots, n$ (the total number of individuals), and $t$ denotes the period in the panel dataset, $t=1, \ldots, T_{i}$ (unbalanced panel)); $x_{i t}$ is a vector of socio-demographic and economic characteristics (such as educational attainment level, marital status, and non-labor income); $\beta$ is the corresponding vector of parameters to be estimated; and $d_{i, t-1}$ is a (observed) binary lagged dependent variable indicating whether an immigrant $i$ was employed in the previous period $(t-1)$. We interpret parameter $\lambda$ as the structural state dependence following Heckman (1981). ${ }^{2}$ age and ysm (years-since-migration) are two key variables for our assimilation model, and their second-order terms $\left(a g e^{2}\right.$ and $\left.y s m^{2}\right)$ are used in the estimation specification but are not presented here to simplify the presentation. Immigrants arrive in different cohorts, $C_{j}$, and these yearly indicator variables aim to capture unobserved arrival yearspecific characteristics, i.e., cohort fixed effects. The transitory macroeconomic fluctuations in the Swedish economy (such as upward or downward trend in unemployment rates during observation periods) may have different impacts on the employment abilities of immigrants and natives. In order to control for these characteristics, the period effects, $\Pi_{k}^{I}$, are included for $k$ observation periods.

In order to calculate the relative employment outcomes of immigrants, we need to estimate the dynamic employment probability-generating function of native Swedes $(N)$ :

$$
\begin{aligned}
& d_{i t}^{N}=1\left(x_{i t}^{\prime} N \beta^{N}+\lambda^{N} d_{i, t-1}^{N}+\varphi^{N} a g e_{i t}^{N}+\sum_{k} \theta_{k}^{N} \Pi_{k}^{N}+u_{i t}^{N}>0\right), \\
& u_{i t}^{N}=\eta_{i}^{N}+\varepsilon_{i t}^{N}, \\
& d_{i 1}^{N}=1\left(z_{i 1}^{\prime} N \beta_{1}^{N}+u_{i 1}^{N}>0\right),
\end{aligned}
$$

where the variables years-since-migration and arrival cohorts, which are not relevant for the data-generating process of natives, are excluded. The definition of other terms is the same as in the case of immigrants.

\subsubsection{Identification}

The model given in (1) is not identified. The period effects is a linear combination of arrival cohort and years-since-migration, since the calendar year at any cross section is the sum of the years-since-migration and the year in which the individual immigration occurred $\left(\Pi_{k}=C_{j}+y s m\right)$. An additional restriction must be imposed: either that the period effect is the same for both immigrants and native Swedes or that the cohort effect is the same across different arrival cohorts, and thus, we can drop it from the model. Several strategies are used in the literature to identify this model. The assumption 
that the period effects of immigrants and natives are the same (i.e., $\Pi_{k}^{I}=\Pi_{k}^{N} ; \forall k$ ) is credible if there are no changes in macroeconomic conditions or, if there is a change, the responsiveness of immigrants and natives to these changes are the same. The drawback of this assumption is that changing macroeconomic conditions may influence the price paid for skills of immigrants and natives differently. Thus, if the sensitivities of immigrants and native Swedes are in fact different and if they are not equally affected by changing macroeconomic conditions, this restriction can lead to a severe bias in the estimates of arrival cohort effect and years-since-migration (Barth et al. 2004). In fact, Sweden (and the other Nordic countries) experienced a sharp economic downturn coinciding with our sample period, 1990-2000. Thus, the model, which assumes equal period effects, is biased, and most importantly, this bias might affect the state dependence parameter of natives and immigrants differently. To deal with this issue, our first strategy is to use the local unemployment rates (at the municipality level for each period of observations) by following the wage curve approach suggested in Barth et al. (2004). Second, we group the arrival cohorts into 5-year intervals (the details are given below), allowing us to control for age, year-since-migration, and year fixed effects at the same model specification simultaneously.

\subsubsection{Stochastic specifications}

The error terms in (1) and (4) are composed as in (2) and (5). The first part, $\eta_{i}$, is the time-invariant unobserved individual effects, and controlling for these factors is crucial in order to be able to identify structural state dependence. The second part $\varepsilon_{i t}$ is the usual error terms, which are assumed to have a normal distribution with zero mean and unit variance due to identification of the probit model. The specification is a random-effects model that assumes that observed and unobserved characteristics are orthogonal. Yet, this assumption is very strong and can easily be violated (for instance, unobserved taste for work for immigrants can be correlated with experience and education). We use the quasi-fixed effects or otherwise known as the correlated randomeffects model of Chamberlain (1984) or Mundlak's (1978) formulation. The actual disturbance process is assumed to be serially uncorrelated. However, in this model, allowing for an unobserved individual effect induces a serial correlation. The correlation between two sequential error terms is given as $\operatorname{Corr}\left(\varepsilon_{i t}, \varepsilon_{i s}\right)=\frac{\sigma_{\eta}^{2}}{\sigma_{\eta}^{2}+1} ;\left(t, s=1, \ldots, T_{i} ; t \neq s\right)$ , where $\sigma_{\eta}^{2}$ is the variance of the unobserved individual effects.

The dynamic models specified in (1-3) and (4-6) are estimated using the randomeffects specification. ${ }^{3}$ In this case, such an approach requires correct specification of the distribution of the initial values and unobserved individual effects. The loglikelihood function of our dynamic model is specified as follows:

$$
\begin{aligned}
& \log (L)=\sum_{i=1}^{n} \ln \left[\int_{-\infty}^{\infty}\left\{f_{i 1}\left(d_{i 1} \mid\left\{X_{i t}\right\}_{t=1}^{T_{i}}, \eta_{i}\right) \prod_{t=2}^{T_{i}} f_{i t}\left(d_{i t} \mid d_{i, t-1}, X_{i t}, \eta_{i} ; \beta\right)\right\} f\left(\eta_{i}\right) d \eta_{i}\right] \\
& f_{i t}\left(d_{i t} \mid d_{i, t-1}, X_{i t}, \eta_{i} ; \beta\right)=\Phi\left[\left(2 d_{i t}-1\right)\left(X^{\prime}{ }_{i t} \beta+\lambda d_{i, t-1}+\sigma_{\eta} \eta_{i}\right)\right]
\end{aligned}
$$

where $X_{i t}$ is a vector including all observed variables (except the lagged dependent variable); $\beta$ is a vector of the corresponding parameters; and $\Phi$ is the distribution function of the standard normal random variable. The likelihood function in (7) can easily be 
maximized when the conditional distribution of the initial values $f_{i 1}\left(d_{i 1} \mid\left\{X_{i t}\right\}_{t=1}^{T_{i}}, \eta_{i}\right)$ is known. In order to identify the magnitude of the structural state dependence and disentangle it from spurious factors leading to persistence, the initial values play an important role (Heckman 1981; Wooldridge 2005). This problem occurs when some individuals enter into the employment status-generating process before the observation period. Many immigrants (and of course native Swedes) entered the Swedish labor market much earlier than the study period (1990-2000). That is, a substantial portion of individuals had a past employment history before entering the panel (1990 in our case). Thus, it is obvious that the first wave employment status cannot be taken as exogenous. This assumption is very strong and can lead to biased and inconsistent estimators for the parameter estimates of structural model parameters (Heckman 1981). The sample initial employment status must instead be considered endogenous, with a probability distribution conditioned on observed and unobserved individual characteristics.

There are two main methods to solve this problem: Heckman's (1981) reduced form approximation and Wooldridge's (2005) method. Heckman's method is based on available pre-sample information with which the conditional distribution of the initial values can be approximated via a reduced form. This approximation allows a flexible specification of the relationships between the initial values and observed and unobserved individual characteristics. Wooldridge (2005) introduces a simple and novel alternative to Heckman's reduced form approximation. He suggests that the unobserved individual effects can be considered conditional on the initial values and the time-varying exogenous variables in a way similar to the correlated random-effects model of Chamberlain (1984) using a similar auxiliary distribution for the unobserved individual effects. In the present paper, we use the Wooldridge method as we have a long panel dataset (Arulampalam and Stewart 2009; Akay 2012). ${ }^{4}$ In this approach, to solve the initial values problem, the auxiliary distribution of the unobserved individual effects for immigrants and natives is specified as follows:

$$
\begin{aligned}
& \eta_{i}^{I}=\pi_{0}^{I}+\pi_{1}^{I} d_{i 1}^{I}+\pi_{2}^{I} \bar{z}_{i}^{I}+\alpha_{i}^{I}, \\
& \eta_{i}^{N}=\pi_{0}^{N}+\pi_{1}^{N} d_{i 1}^{N}+\pi_{2}^{N} \bar{z}_{i}^{N}+\alpha_{i}^{N},
\end{aligned}
$$

where $d_{i 1}^{I}$ and $d_{i 1}^{N}$ are the first-period employment status of immigrants and natives; $\bar{z}_{i}^{I}$ and $\bar{z}_{i}^{N}$ are the within means of the time-variant variables that are considered to be correlated with the unobserved individual effect $\eta_{i}$. The time-variant variables used in (9) and (10) are age, year-since-migration (for immigrants), education, non-labor income, number of children at home, local unemployment rates, and national unemployment rates in the arrival year. $\alpha_{i}$ is the new unobserved individual effect, which is now assumed to be normally distributed with zero mean and a finite variance and uncorrelated with the observed characteristics.

\subsubsection{The estimators of employment assimilation}

The approach adopted here to measure employment assimilation is based on the idea of assimilation having occurred when immigrants' employment probability levels catch up with those of natives (following Borjas 1985, 1999). To calculate the relative employment probabilities, we are going to simulate the conditional expected values of the dynamic and static models over the life cycle of natives and immigrants. The simplified 
conditional expectations of the dynamic system-generating employment probabilities are written as follows:

$$
\begin{aligned}
& E^{I}\left[d_{i t}=1 \mid X_{i t}, d_{i, t-1}, \operatorname{age}_{i t}, y s m_{i t}, \alpha_{i}\right]=\Phi\left[\begin{array}{c}
X_{i t}^{\prime} \hat{\beta}^{I}+\lambda d_{i, t-1}+ \\
\hat{\varphi}^{I} \operatorname{age}_{i t}\left(\tau_{0}+\tau\right)+\hat{\phi}^{I} y \operatorname{sm}_{i t}\left(\tau_{0}\right)
\end{array}\right], \\
& E^{N}\left[d_{i t}=1 \mid X_{i t}, d_{i, t-1}, \operatorname{age}_{i t}, \alpha_{i}\right]=\Phi\left[X^{\prime}{ }_{i t} \hat{\beta}^{N}+\lambda d_{i, t-1}+\hat{\varphi}^{N} \operatorname{age}_{i t}\left(\tau_{0}+\tau\right)\right]
\end{aligned}
$$

Our strategy to calculate the employment probability differentials is as follows: First, we assume that the labor market entry age is $\tau_{0}=20$ for each immigrant and native. We predict the employment probability for each immigrant and native at age $=20$ and $y s m=0$ to calculate the initial employment probability differential upon arrival. We then increase $\tau$ up to 45 (implying that the age of the individuals is increased up to 65) and predict the employment probabilities for each year-since-migration. One important issue is how to treat past employment status $d_{i, t-1}$ and unobserved individual effects $\alpha_{i}$ in the simulations. There can be several strategies to simulate the life cycle employment probabilities in the case of the dynamic model. Yet, since one of our aims is to compare the results from the dynamic and the static model, the simulation strategy should allow us to directly compare the outcomes of these models. We also note that our estimation strategy assumes that the lagged employment status is "observed"; see Eqs. (1-3) and (4-6). Thus, the straightforward approach is simply to treat past employment status as one of the other (observed) control variables, conditional on the initial conditions specifications defined in (9) and (10). This implies that the difference between the static and dynamic models in our simulations is only due to past employment status and the first-year employment status. Our strategy to deal with the unobserved individual effect is to simply evaluate the unobserved effect at the mean for everyone, $\alpha_{i}=0$, both for the dynamic and the static model. The standard errors of the prediction are also calculated for each age and year-since-migration combinations to calculate the $95 \%$ confidence intervals.

\section{Data}

\subsection{Sample selection}

The dataset used is the Swedish register-based Longitudinal Individual Dataset (LINDA) observed between 1990 and 2000. LINDA consists of a population sample and a sample of first-generation immigrants; the population sample includes $3.35 \%$ of the entire population each year, and the migrant sample includes almost $20 \%$ of all immigrants. In Sweden, immigrants are entered into the national register (and thus the sampling frame) when they receive a residence permit. The dataset is updated with current household information each year based on data from the population and housing censuses, the official income register, and higher education registers (for more details on LINDA, see Edin and Frederiksson 2000).

In this paper, we focus only on male immigrants since the labor market behavior differs substantially between male and female immigrants. This also enables us to focus more deeply on the research question in this paper. In order to avoid further selection problems due to retirement at age 65, the 33,504 immigrant men aged 18-55 in 1990 are initially selected for the study as well as an equally large control group of randomly selected native Swedish men, matched by age and county of residence. An additional 
$20 \%$ of the new set of immigrants (2000 to 4000) is also added each year, as well as an equal number of randomly selected native Swedes is also matched. By 2000, these unbalanced panels consisted of around 65,000 immigrant men (generating 521,686 individual year observations for immigrants and 540,651 for natives). We also exclude the self-employed, since their employment conditions are considerably different from wage workers. ${ }^{5}$

\subsection{Key measures}

The key variable in this study is employment status. There are many different ways to define an indicator for employment. To minimize the measurement error, information on whether an individual is employed or not is obtained from the national income registers by using the gross labor income of the individuals. First, we measure the annual gross labor income in Swedish kronor (SEK) using the income registers (we inflate the values by the consumer price index to 2000 prices). It is easier to select the individuals as not working if the gross labor income is zero. We follow Antelius and Björklund (2000), who consider an individual as employed if annual earnings are at least 36,400 SEK. In our case, this eliminates those in the military service, with short employment spells, and with part-time jobs with low pay. ${ }^{6}$ Thus, based on this criterion, the employment indicator $\left(d_{i t}\right)$ is defined as 1 if the individual $i$ at time period $t$ is employed and 0 otherwise.

We split the immigrants by seven regions of origin: Nordic countries, Western countries (including the USA, Canada, Australia, and New Zealand), Eastern Europe, Middle East, Asia, Africa, and Latin America. We also control for a rich set of sociodemographic and economic characteristics of the individuals. The variables are age and age squared, years-since-migration (and squared), marital status (cohabiting is considered being married), number of children living at home, highest attained level of education (primary education, i.e., 9 years of education; secondary education, i.e., high school diploma and more than 9 but fewer than 12 years of education; and university education), residence in Stockholm or elsewhere, capital non-labor income, arrival cohorts (7 arrival cohorts split ${ }^{7}$ by 5 -year intervals), year fixed effects, and local unemployment rates. ${ }^{8}$

\subsection{Descriptive statistics}

Table 1 shows the mean values of our main control variables for both immigrants and native Swedes. The employment rate figures are very much in line with previous studies (Bevelander and Nielsen 2001; Hammarstedt 2001, 2003; Bevelander 2005). The employment rates ( $83 \%$ vs. 37-68 \%) are considerably higher for native Swedes. The reverse is true for being married or cohabiting ( $40 \%$ vs. 38-59 \%). Native Swedes are generally better educated: About $77 \%$ have at least upper-secondary education, compared with 61-77 \% for immigrants. The earlier migrant cohorts account for 9-12\%, whereas 1985-1989 and 1990-1994 account for 18 and $25 \%$, respectively. These large figures might be explained by the Iran-Iraq War and various conflicts in the former Yugoslavia that occurred during these periods. The Nordic area accounts for $25 \%$ of all immigrants, followed by the Middle East (23\%), Eastern Europe (21 \%), Western countries (14\%), and Asia, Africa, and Latin America, each with 5-6\%. 
Table 1 Descriptive statistics: native Swedes and immigrants, 1990-2000

\begin{tabular}{|c|c|c|c|c|c|c|c|c|}
\hline & $\begin{array}{l}\text { Native } \\
\text { Swedes }\end{array}$ & $\begin{array}{l}\text { Nordic } \\
\text { countries }\end{array}$ & $\begin{array}{l}\text { Western } \\
\text { countries }\end{array}$ & $\begin{array}{l}\text { Eastern } \\
\text { Europe }\end{array}$ & $\begin{array}{l}\text { Middle } \\
\text { East }\end{array}$ & Asia & Africa & $\begin{array}{l}\text { Latin } \\
\text { America }\end{array}$ \\
\hline Log of earnings & $\begin{array}{l}10.78 \\
(3.73)\end{array}$ & $\begin{array}{l}8.99 \\
(5.14)\end{array}$ & $\begin{array}{l}8.06 \\
(5.51)\end{array}$ & $\begin{array}{l}7.83 \\
(5.71)\end{array}$ & $\begin{array}{l}5.67 \\
(5.58)\end{array}$ & $\begin{array}{l}7.54 \\
(5.36)\end{array}$ & $\begin{array}{l}6.27 \\
(5.53)\end{array}$ & $\begin{array}{l}7.84 \\
(5.16)\end{array}$ \\
\hline Employment status & $\begin{array}{l}0.82 \\
(0.37)\end{array}$ & $\begin{array}{l}0.68 \\
(0.47)\end{array}$ & $\begin{array}{l}0.59 \\
(0.49)\end{array}$ & $\begin{array}{l}0.49 \\
(0.50)\end{array}$ & $\begin{array}{l}0.37 \\
(0.48)\end{array}$ & $\begin{array}{l}0.51 \\
(0.50)\end{array}$ & $\begin{array}{l}0.40 \\
(0.49)\end{array}$ & $\begin{array}{l}0.56 \\
(0.49)\end{array}$ \\
\hline $\begin{array}{l}\text { First lag of } \\
\text { employment }\end{array}$ & $\begin{array}{l}0.83 \\
(0.37)\end{array}$ & $\begin{array}{l}0.69 \\
(0.45)\end{array}$ & $\begin{array}{l}0.60 \\
(0.49)\end{array}$ & $\begin{array}{l}0.47 \\
(0.49)\end{array}$ & $\begin{array}{l}0.36 \\
(0.48)\end{array}$ & $\begin{array}{l}0.50 \\
(0.50)\end{array}$ & $\begin{array}{l}0.39 \\
(0.48)\end{array}$ & $\begin{array}{l}0.55 \\
(0.50)\end{array}$ \\
\hline Employment in 1990 & $\begin{array}{l}0.83 \\
(0.38)\end{array}$ & $\begin{array}{l}0.74 \\
(0.44)\end{array}$ & $\begin{array}{l}0.61 \\
(0.49)\end{array}$ & $\begin{array}{l}0.42 \\
(0.49)\end{array}$ & $\begin{array}{l}0.38 \\
(0.48)\end{array}$ & $\begin{array}{l}0.44 \\
(0.50)\end{array}$ & $\begin{array}{l}0.36 \\
(0.49)\end{array}$ & $\begin{array}{l}0.56 \\
(0.50)\end{array}$ \\
\hline $\begin{array}{l}\text { Local unemployment } \\
\text { rate }\end{array}$ & $\begin{array}{l}2.81 \\
(1.18)\end{array}$ & $\begin{array}{l}2.66 \\
(1.01)\end{array}$ & $\begin{array}{l}2.83 \\
(1.26)\end{array}$ & $\begin{array}{l}2.85 \\
(1.11)\end{array}$ & $\begin{array}{l}3.35 \\
(1.55)\end{array}$ & $\begin{array}{l}3.21 \\
(1.48)\end{array}$ & $\begin{array}{l}3.15 \\
(1.34)\end{array}$ & $\begin{array}{l}3.01 \\
(1.41)\end{array}$ \\
\hline Age & $\begin{array}{l}38.7 \\
(10.8)\end{array}$ & $\begin{array}{l}40.7 \\
(10.8)\end{array}$ & $\begin{array}{l}39.2 \\
(10.96)\end{array}$ & $\begin{array}{l}38.9 \\
(11.2)\end{array}$ & $\begin{array}{l}35.6 \\
(9.46)\end{array}$ & $\begin{array}{l}33.3 \\
(10.5)\end{array}$ & $\begin{array}{l}33.1 \\
(9.15)\end{array}$ & $\begin{array}{l}35.4 \\
(10.8)\end{array}$ \\
\hline Years-since-migration & - & $\begin{array}{l}19.0 \\
(9.40)\end{array}$ & $\begin{array}{l}14.8 \\
(9.76)\end{array}$ & $\begin{array}{l}12.2 \\
(9.64)\end{array}$ & $\begin{array}{l}9.77 \\
(6.49)\end{array}$ & $\begin{array}{l}12.6 \\
(7.62)\end{array}$ & $\begin{array}{l}8.59 \\
(6.32)\end{array}$ & $\begin{array}{l}12.1 \\
(6.80)\end{array}$ \\
\hline Married/cohabiting & $\begin{array}{l}0.40 \\
(0.49)\end{array}$ & $\begin{array}{l}0.39 \\
(0.49)\end{array}$ & $\begin{array}{l}0.47 \\
(0.50)\end{array}$ & $\begin{array}{l}0.59 \\
(0.49)\end{array}$ & $\begin{array}{l}0.55 \\
(0.50)\end{array}$ & $\begin{array}{l}0.47 \\
(0.50)\end{array}$ & $\begin{array}{l}0.44 \\
(0.50)\end{array}$ & $\begin{array}{l}0.38 \\
(0.48)\end{array}$ \\
\hline $\begin{array}{l}\text { Number of children at } \\
\text { home }\end{array}$ & $\begin{array}{l}1.78 \\
(1.16)\end{array}$ & $\begin{array}{l}1.61 \\
(1.12)\end{array}$ & $\begin{array}{l}1.66 \\
(1.12)\end{array}$ & $\begin{array}{l}1.81 \\
(1.20)\end{array}$ & $\begin{array}{l}1.97 \\
(1.47)\end{array}$ & $\begin{array}{l}1.70 \\
(1.26)\end{array}$ & $\begin{array}{l}1.58 \\
(1.54)\end{array}$ & $\begin{array}{l}1.69 \\
(1.21)\end{array}$ \\
\hline Stockholm residence & $\begin{array}{l}0.22 \\
(0.43)\end{array}$ & $\begin{array}{l}0.35 \\
(0.44)\end{array}$ & $\begin{array}{l}0.39 \\
(0.47)\end{array}$ & $\begin{array}{l}0.22 \\
(0.34)\end{array}$ & $\begin{array}{l}0.37 \\
(0.45)\end{array}$ & $\begin{array}{l}0.30 \\
(0.42)\end{array}$ & $\begin{array}{l}0.40 \\
(0.48)\end{array}$ & $\begin{array}{l}0.43 \\
(0.51)\end{array}$ \\
\hline Non-labor income & $\begin{array}{l}0.74 \\
(2.26)\end{array}$ & $\begin{array}{l}0.49 \\
(1.83)\end{array}$ & $\begin{array}{l}0.56 \\
(1.99)\end{array}$ & $\begin{array}{l}0.45 \\
(1.76)\end{array}$ & $\begin{array}{l}0.54 \\
(1.91)\end{array}$ & $\begin{array}{l}0.62 \\
(2.03)\end{array}$ & $\begin{array}{l}0.27 \\
(1.35)\end{array}$ & $\begin{array}{l}0.30 \\
(1.44)\end{array}$ \\
\hline Lower secondary & $\begin{array}{l}0.23 \\
(0.37)\end{array}$ & $\begin{array}{l}0.31 \\
(0.44)\end{array}$ & $\begin{array}{l}0.32 \\
(0.46)\end{array}$ & $\begin{array}{l}0.23 \\
(0.39)\end{array}$ & $\begin{array}{l}0.45 \\
(0.48)\end{array}$ & $\begin{array}{l}0.39 \\
(0.47)\end{array}$ & $\begin{array}{l}0.32 \\
(0.45)\end{array}$ & $\begin{array}{l}0.40 \\
(0.47)\end{array}$ \\
\hline Upper secondary & $\begin{array}{l}0.51 \\
(0.49)\end{array}$ & $\begin{array}{l}0.43 \\
(0.50)\end{array}$ & $\begin{array}{l}0.36 \\
(0.47)\end{array}$ & $\begin{array}{l}0.51 \\
(0.50)\end{array}$ & $\begin{array}{l}0.39 \\
(0.49)\end{array}$ & $\begin{array}{l}0.37 \\
(0.48)\end{array}$ & $\begin{array}{l}0.46 \\
(0.50)\end{array}$ & $\begin{array}{l}0.47 \\
(0.49)\end{array}$ \\
\hline University degree & $\begin{array}{l}0.26 \\
(0.43)\end{array}$ & $\begin{array}{l}0.26 \\
(0.42)\end{array}$ & $\begin{array}{l}0.32 \\
(0.46)\end{array}$ & $\begin{array}{l}0.26 \\
(0.43)\end{array}$ & $\begin{array}{l}0.26 \\
(0.43)\end{array}$ & $\begin{array}{l}0.24 \\
(0.43)\end{array}$ & $\begin{array}{l}0.22 \\
(0.41)\end{array}$ & $\begin{array}{l}0.23 \\
(0.42)\end{array}$ \\
\hline \multicolumn{9}{|l|}{ Arrival cohort } \\
\hline$<1970$ & - & $\begin{array}{l}0.22 \\
(0.44)\end{array}$ & $\begin{array}{l}0.10 \\
(0.23)\end{array}$ & $\begin{array}{l}0.10 \\
(0.29)\end{array}$ & $\begin{array}{l}0.03 \\
(0.17)\end{array}$ & $\begin{array}{l}0.03 \\
(0.19)\end{array}$ & $\begin{array}{l}0.03 \\
(0.20)\end{array}$ & $\begin{array}{l}0.04 \\
(0.25)\end{array}$ \\
\hline 1970-1974 & - & $\begin{array}{l}0.23 \\
(0.42)\end{array}$ & $\begin{array}{l}0.17 \\
(0.37)\end{array}$ & $\begin{array}{l}0.14 \\
(0.35)\end{array}$ & $\begin{array}{l}0.04 \\
(0.18)\end{array}$ & $\begin{array}{l}0.10 \\
(0.31)\end{array}$ & $\begin{array}{l}0.04 \\
(0.21)\end{array}$ & $\begin{array}{l}0.05 \\
(0.22)\end{array}$ \\
\hline 1975-1979 & - & $\begin{array}{l}0.21 \\
(0.40)\end{array}$ & $\begin{array}{l}0.16 \\
(0.36)\end{array}$ & $\begin{array}{l}0.08 \\
(0.26)\end{array}$ & $\begin{array}{l}0.11 \\
(0.31)\end{array}$ & $\begin{array}{l}0.21 \\
(0.41)\end{array}$ & $\begin{array}{l}0.07 \\
(0.26)\end{array}$ & $\begin{array}{l}0.21 \\
(0.40)\end{array}$ \\
\hline 1980-1984 & - & $\begin{array}{l}0.09 \\
(0.28)\end{array}$ & $\begin{array}{l}0.13 \\
(0.33)\end{array}$ & $\begin{array}{l}0.10 \\
(0.30)\end{array}$ & $\begin{array}{l}0.12 \\
(0.32)\end{array}$ & $\begin{array}{l}0.18 \\
(0.39)\end{array}$ & $\begin{array}{l}0.08 \\
(0.27)\end{array}$ & $\begin{array}{l}0.18 \\
(0.38)\end{array}$ \\
\hline 1985-1989 & - & $\begin{array}{l}0.13 \\
(0.33)\end{array}$ & $\begin{array}{l}0.18 \\
(0.38)\end{array}$ & $\begin{array}{l}0.14 \\
(0.34)\end{array}$ & $\begin{array}{l}0.35 \\
(0.48)\end{array}$ & $\begin{array}{l}0.19 \\
(0.39)\end{array}$ & $\begin{array}{l}0.30 \\
(0.45)\end{array}$ & $\begin{array}{l}0.33 \\
(0.47)\end{array}$ \\
\hline 1990-1994 & - & $\begin{array}{l}0.09 \\
(0.29)\end{array}$ & $\begin{array}{l}0.17 \\
(0.37)\end{array}$ & $\begin{array}{l}0.38 \\
(0.48)\end{array}$ & $\begin{array}{l}0.29 \\
(0.45)\end{array}$ & $\begin{array}{l}0.24 \\
(0.43)\end{array}$ & $\begin{array}{l}0.42 \\
(0.50)\end{array}$ & $\begin{array}{l}0.15 \\
(0.36)\end{array}$ \\
\hline 1995-2000 & - & $\begin{array}{l}0.03 \\
(0.17)\end{array}$ & $\begin{array}{l}0.09 \\
(0.17)\end{array}$ & $\begin{array}{l}0.06 \\
(0.24)\end{array}$ & $\begin{array}{l}0.06 \\
(0.24)\end{array}$ & $\begin{array}{l}0.05 \\
(0.22)\end{array}$ & $\begin{array}{l}0.06 \\
(0.23)\end{array}$ & $\begin{array}{l}0.04 \\
(0.20)\end{array}$ \\
\hline $\begin{array}{l}\text { Number of } \\
\text { observations }\end{array}$ & 540,651 & 131,647 & 67,641 & 107,124 & 121,914 & 28,381 & 28,432 & 36,547 \\
\hline
\end{tabular}

Standard deviations in parentheses

The migrant population is clearly not homogenous: Employment rates are much higher for those from Nordic or Western countries (68 and $59 \%$ ). Middle Eastern and African immigrants are far less likely to be employed (37 and $40 \%$ ). Immigrants from non-Nordic Western countries have more education than all other groups (nearly $32 \%$ have a university degree), followed by Eastern Europeans. Despite the fact that Nordic 
immigrants, most of them from Finland, have less education, they have higher employment rates compared to most other immigrant groups. The descriptive statistics are generally in line with previous studies on immigrants in Sweden.

\subsection{Unconditional patterns of employment status transitions}

Table 2 reports raw transition patterns of employment status of native Swedes and immigrant groups for different degrees of transitions to work or from work. The third column presents the proportion of individuals who were employed for 11 years without any change in employment status, and the fourth column gives the proportion of those employed for 0 year without any transition. Being employed in every period implies a binary sequence of employment status of $(1,1, \ldots, 1)$ (where employed $=1$; otherwise 0 ). Sixty-one percent of native Swedes were employed in all periods, and only $7.5 \%$ were not employed in any period $(0,0, \ldots, 0)$. Native Swedes are followed by Nordic and Western countries, with a relatively high rate of employment (44 and $34 \%$ ) and a relatively low rate of unemployment in all periods (16 and $24 \%$ ). The raw employment status transition patterns of other migrant regions suggest that immigrants tend to experience several interruptions in their employment status as they frequently transit from work and to work. For instance, only 10-11\% of immigrants from the Middle East and Africa are continuously employed in all periods and 25-30\% are not employed in any period.

The fifth column presents the proportion of individuals with a single transition from employment to unemployment. For instance, a single transition from work implies an employment status sequence of $(1, \ldots, 1,0,0, \ldots, 0)$. These are the individuals who become unemployed and then stay in unemployment for the remainder of the sample period. The frequency of a single transition from work is lowest for native Swedes $(6.5 \%)$ and highest among Nordic and Western immigrants (12 and $11 \%$, respectively). A single transition to work (from unemployment to employment, sixth column) implies a sequence of $(0, \ldots, 0,1,1, \ldots, 1)$. Across the sample period, migrant groups (except Nordics) exhibit a very high degree of single transition to work. The highest value is found for Eastern Europeans (28 \%) followed by Asians and Africans (25 and $21 \%$ ).

The last column is for multiple transitions of any kind, i.e., binary employment status sequences such as $(0, \ldots, 1,0,1, \ldots, 1)$ or $(1, \ldots, 0,1,0, \ldots, 0)$. We calculate the figures in the last column by considering transitions occurring at least twice. Native Swedes, Nordics,

Table 2 Employment status transitions by natives and immigrants' region of origin

\begin{tabular}{lllllll}
\hline $\begin{array}{l}\text { Region of } \\
\text { origin }\end{array}$ & $\begin{array}{l}\text { Number of } \\
\text { individuals }\end{array}$ & $\begin{array}{l}\text { Employed all } \\
\text { periods }\end{array}$ & $\begin{array}{l}\text { Employed } 0 \\
\text { periods }\end{array}$ & $\begin{array}{l}\text { Single transition } \\
\text { from work }\end{array}$ & $\begin{array}{l}\text { Single transition } \\
\text { to work }\end{array}$ & $\begin{array}{l}\text { Multiple } \\
\text { transitions }\end{array}$ \\
\hline Native Swedes & 65,842 & $0.613(0.487)$ & $0.075(0.263)$ & $0.065(0.245)$ & $0.081(0.273)$ & $0.165(0.371)$ \\
Nordic countries & 15,578 & $0.443(0.497)$ & $0.162(0.369)$ & $0.116(0.320)$ & $0.063(0.243)$ & $0.215(0.410)$ \\
Western countries & 8541 & $0.338(0.473)$ & $0.238(0.425)$ & $0.113(0.316)$ & $0.110(0.312)$ & $0.201(0.401)$ \\
Eastern Europe & 13,628 & $0.187(0.390)$ & $0.258(0.434)$ & $0.072(0.259)$ & $0.275(0.446)$ & $0.212(0.408)$ \\
Middle East & 14,564 & $0.100(0.298)$ & $0.300(0.458)$ & $0.095(0.293)$ & $0.180(0.384)$ & $0.325(0.469)$ \\
Asia & 3333 & $0.168(0.373)$ & $0.207(0.405)$ & $0.076(0.264)$ & $0.247(0.431)$ & $0.302(0.458)$ \\
Africa & 3267 & $0.110(0.313)$ & $0.249(0.432)$ & $0.081(0.273)$ & $0.218(0.413)$ & $0.339(0.473)$ \\
Latin America & 4057 & $0.202(0.401)$ & $0.148(0.355)$ & $0.093(0.290)$ & $0.207(0.405)$ & $0.349(0.476)$ \\
\hline
\end{tabular}

Standard deviations in parentheses 
Westerners, and Eastern Europeans do not experience a high degree of multiple transitions compared with other immigrants groups (17, 22, 20, and $21 \%$ ). Almost 30-35\% of other immigrant groups experience transitions more than twice. It is very clear from the unconditional data that the patterns of persistence and transition differ substantially between immigrants and natives.

\section{Estimation results}

Our main interest is in determining the magnitude of structural state dependence for natives and immigrant groups. We predict relative employment probabilities as a function of years-since-migration based on the static and dynamic models. We later present state dependence and predictions of the relative employment probabilities by educational attainment levels.

\subsection{Main results}

The models given in (1-3) and (4-6) are estimated for seven regions of origin. ${ }^{9}$ The models estimated here have non-linear expected values, and thus, our main measure of interest is the average marginal effects of past employment experience on the current employment probabilities (lagged dependent variable), conditional on the observed and unobserved individual characteristics and endogenous initial values. The marginal effects of structural state dependence are reported in Table 3. There is substantial and highly significant structural state dependence on the employment status of both natives and immigrants. The lagged employment status is associated with a higher probability of being employed in the current period. Table 3 shows that natives experience substantially higher structural state dependence than immigrants. The highest level of state dependence is experienced by Eastern Europeans, Westerners, and Latin Americans. One surprising and potentially important finding is that the persistence of employment status is found to be low for Nordic male immigrants, despite the fact that these individuals display very similar characteristics to Swedish natives, e.g., linguistic and cultural similarities. Perhaps it is the very close geographical proximity that leads Nordic immigrants to experience discontinuities in their work experience, yet we do not have information (for instance about the circular immigration) to investigate this issue further.

Table 3 also reports the variance of the unobserved individual effects, which might be considered a proxy for the extent of the spurious factors leading to persistence. Conditional on the lagged employment status (and all other control variables), immigrants are found to be more heterogeneous than native Swedes in their unobserved characteristics. It is well known that immigrants are self-selected group of individuals and this is represented by the large size of variance of the unobserved characteristics. To show the effect of the dynamic assimilation model on the distribution of the unobserved individual effects, we also report the variance obtained from the static assimilation model (in brackets). One important finding is that the size of the variance obtained from the static model shrinks when the model is controlled for the lagged employment status, as expected. The static model represents persistence only through time-invariant individual characteristics. It is clear that the failure to control for the structural state dependence leads to an overestimation of the variance of the unobserved individual effects. 
Table 3 Structural state dependence on the employment probabilities of immigrants and natives by region of origin

\begin{tabular}{|c|c|c|c|c|c|c|c|c|}
\hline & \multicolumn{8}{|l|}{ Region of origin } \\
\hline & Nordic countries & Western countries & Eastern Europe & Middle East & Asia & Africa & Latin America & Native Swedes \\
\hline Lagged employment status $(\lambda)$ & $0.509^{* * *}(0.010)$ & $0.574^{* * *}(0.009)$ & $0.586^{* * *}(0.010)$ & $0.470^{* * *}(0.011)$ & $0.527^{* * *}(0.011)$ & $0.526^{* * *}(0.010)$ & $0.553^{* * *}(0.010)$ & $0.805^{* * *}(0.007)$ \\
\hline$\sigma_{a}$ & $0.885[1.921]$ & $0.879[1.971]$ & $0.578[1.507]$ & $0.542[1.194]$ & $0.619[1.383]$ & $0.504[1.163]$ & $0.573[1.281]$ & $0.500[1.611]$ \\
\hline
\end{tabular}




\subsection{Employment assimilation: comparing the dynamic and static models}

We now predict the relative employment probabilities of immigrants as a function of years-since-migration using the framework described in Section 2. As mentioned, to simulate the employment probabilities, we assume that everyone enters the labor market at age $\tau_{0}=20$. We have also tried other labor market entry ages from 18 to 22, but the results changed only marginally. The simulations are conducted by using individual values of characteristics for each individual. We later simulate the employment probabilities of natives and immigrants for every year-since-migration from 0 to 45 .

Having obtained the point estimate of relative employment probability for each year-since-migration and the standard errors of each individual prediction, we use them to calculate $95 \%$ confidence intervals for each individual. We then take the average of each individual prediction and also $95 \%$ confidence intervals to produce the average employment probability level and average confidence interval for a year-since-migration. In order to calculate relative employment probabilities, we predict the employment probabilities of native Swedes using a similar strategy.

\subsubsection{Initial employment probabilities}

When year-since-migration is $\tau=0$ and age $\tau_{0}=20$ (it is only age $\tau=20$ for natives), the relative employment probability is the initial employment probability differential upon arrival. We present these results in the second column of Table 4. First of all, there is a substantial employment probability disadvantage of immigrants at the year of arrival compared with an average native Swedish man. The disadvantage is heterogeneous across immigrant groups and models. In general, the dynamic assimilation model predicts a lower initial employment probability disadvantage (except for Nordic immigrants, the static model predicts a 10 percentage points lower initial employment probability disadvantage compared with that of the dynamic model). For instance, the disadvantage of immigrants from the Middle East is predicted to be almost 62 percentage points, which is about 8 percentage points lower compared with the static assimilation model. The overall average disadvantage is estimated to be 55 percentage points (average across all immigrant regions) with the static model while the same figure is predicted to be 45 percentage points by the dynamic model. This implies that the static model overstates the initial employment probability disadvantage by about 10 percentage points, on average.

\subsubsection{Short- and long-run marginal assimilation rates}

Over time, immigrants acquire Swedish labor market-specific skills and improve their employment probabilities relative to a comparable native. Table 4 reports relative employment probabilities for the first 40 years after immigration. We calculate the relative probabilities for each year and then convert the yearly values to averages for each 5-year period (e.g., years-since-migration 1-5 stands for the average employment probability gap experienced in 1-5 years after arrival). Using the same strategy, we calculate the employment probability gap 5 years apart $(1-5,6-10, \ldots, 36-40)$. Almost all immigrant groups are somehow able to reduce the initial employment probability disadvantage in the initial years after arrival as predicted by the assimilation hypothesis. Yet, there are substantial differences between the static and the dynamic model. For instance, according to the static model, immigrants from Asia 
Table 4 Relative employment probabilities and years to assimilation by region of origin: static vs. dynamic model (percentage points)

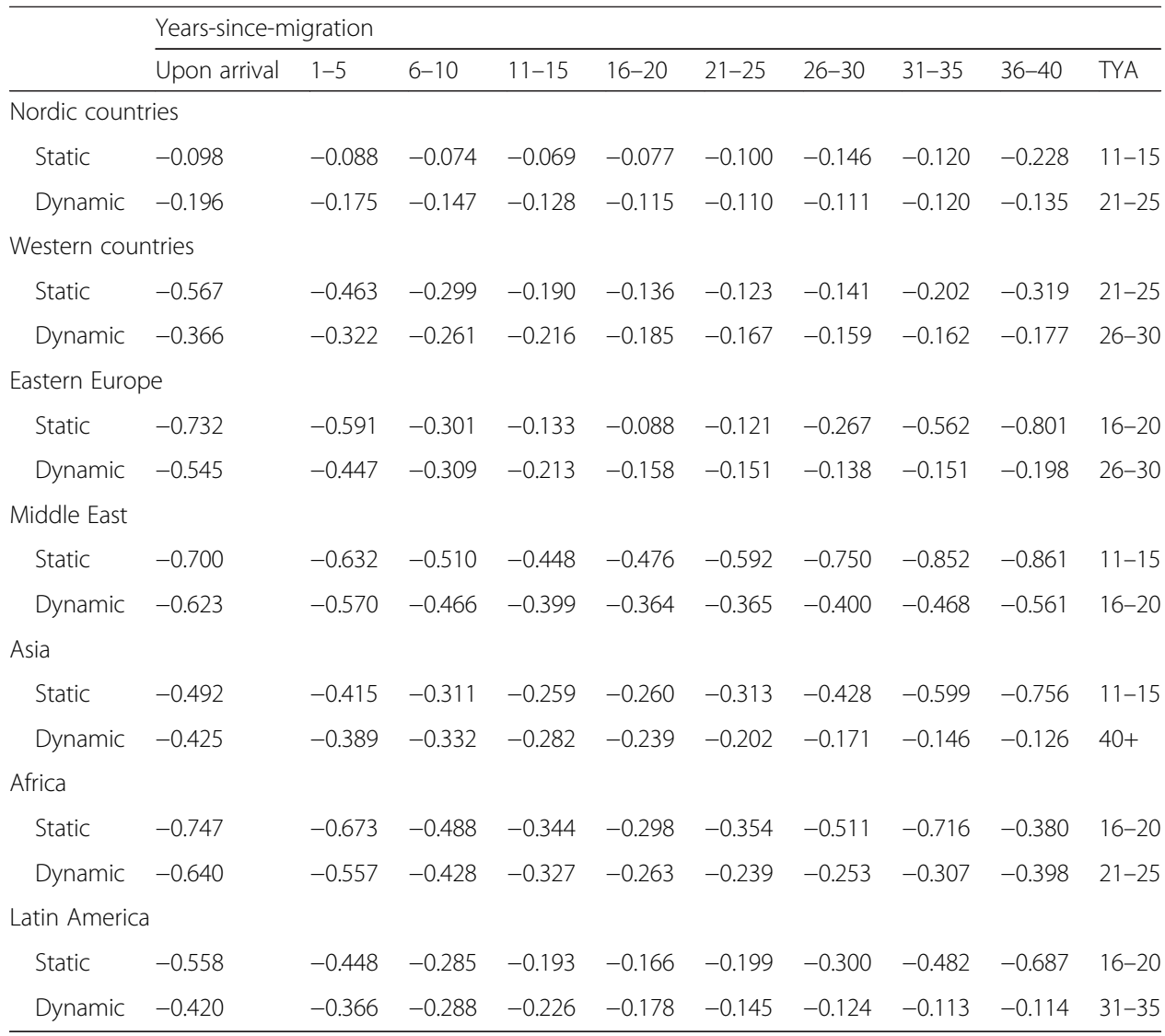

Each figure shows the employment probability differential (percentage points) between immigrants and natives. The figures are calculated by averaging across individuals and 5-year intervals. All figures reported in the table are significantly different than zero at a $1 \%$ significance level. TYA is the total years to assimilation or the year interval in which the employment probability differential is minimized. See Table 3 for the details and the variables used in the model specification

reduce the initial employment probability differential by 7.7 percentage points $(0.492-0.415)$ in 1 to 5 years, 18.1 percentage points $(0.492-0.311)$ in 6 to 10 years, and 23.3 percentage points $(0.492-0.259)$ in 11 to 15 years after arrival. The gap quickly increases after this point and reaches a very high employment probability differential after 40 years of arrival (about 75.6 percentage points). The results from the dynamic model can be interpreted in a similar way. According to the dynamic model, Asian immigrants reduce the initial employment probability gap 3.6 percentage points $(0.425-0.389)$ in 1 to 5 years, 9.3 percentage points $(0.425-$ $0.332)$ in 6 to 10 years, and 14.3 percentage points $(0.425-0.282)$ in 11 to 15 years after arrival. The speed of assimilation is clearly slower compared with that of the static model. Yet, the assimilation process does not stop 11-15 years after arrival, or even after 36-40 years, Asians keep closing the employment probability gap. At about 40 years, Asians reduce the gap to 12.6 percentage points, which is also highly consistent with the raw data. We observe a highly consistent pattern across immigrant groups. In most cases, the dynamic model predicts a lower speed of assimilation during the first years after arrival and longer years of positive marginal assimilation rates. 


\subsubsection{Is there a full assimilation?}

Full assimilation means that an immigrant group catches up with the employment probability level of a comparable native. Our extensive investigation suggests that there is no full assimilation among immigrant men. There is only a partial process of assimilation in most cases. The last column in Table 4 gives the year-sincemigration in which the relative employment probability is minimized for both the static and the dynamic model. According to the static model, almost all migrant groups minimize the gap about 10-20 years after arriving, and then, the gap gradually increases. The predictions of the dynamic model are highly different; it takes almost 10 years longer to minimize the gap, and once it is minimized, the gap stays highly stable for longer periods. For instance, the static model suggests that the Eastern European immigrants minimize the employment probability differential 16-20 years after arrival, and the gap becomes unrealistically large later (the gap is 80.1 percentage point around 40 years after arrival). In contrast, the dynamic model suggests that the Eastern European immigrants are able to keep their marginal assimilation rates positive for 26-30 years, which is 10 years longer. We observe the same pattern in every case. Overall, both models suggest that no immigrant group is able to attain the employment probability levels of native Swedes, at least at the $5 \%$ statistical significance level. The immigrants from Nordic and Western countries are relatively successful. According to the dynamic model, with the exception of Middle Eastern and African immigrants, most immigrant men in Sweden reduce the employment probability gap under 15-20 percentage points. The gap is also partially statistically insignificant for the case of Latin Americans and Asians at the $10 \%$ significance level 40-45 years after arrival.

\subsubsection{Life cycle employment probability profiles}

Next, we present the life cycle patterns of relative employment probabilities to illustrate the differences between the predictions of the static and dynamic assimilation models. We simulate the age-employment-probability profiles of immigrants and natives for each year-since-migration as described above. Figure 1 presents the profiles by immigrants' regions of origin and for both models. The vertical axes in Fig. 1 are the average probability of being employed for each year after arrival. The market entry age is assumed to be 20, and the simulations are performed for 45 years. The vertical lines around the age-employment-probability profile are the (average) $95 \%$ confidence intervals of individual predictions.

Note that the only difference between the static and the dynamic assimilation model is that the dynamic model includes two more explanatory variables: the lagged dependent variable and the first-period employment status. ${ }^{10}$ Yet, the difference between the dynamic and the static assimilation model is striking. A clear pattern across is that the static model overestimates the initial employment probability levels as previously presented in Table 3. The static model also overstates the short-run (early years) speed of assimilation, but understates the long-run (for later years) ones. In other words, it predicts very fast employment probability growth in the initial years after arrival and very fast human capital depreciation rates in the long run. The predictions generated by the static model are very unrealistic, and the difference between the dynamic models is drastic. The predictions 

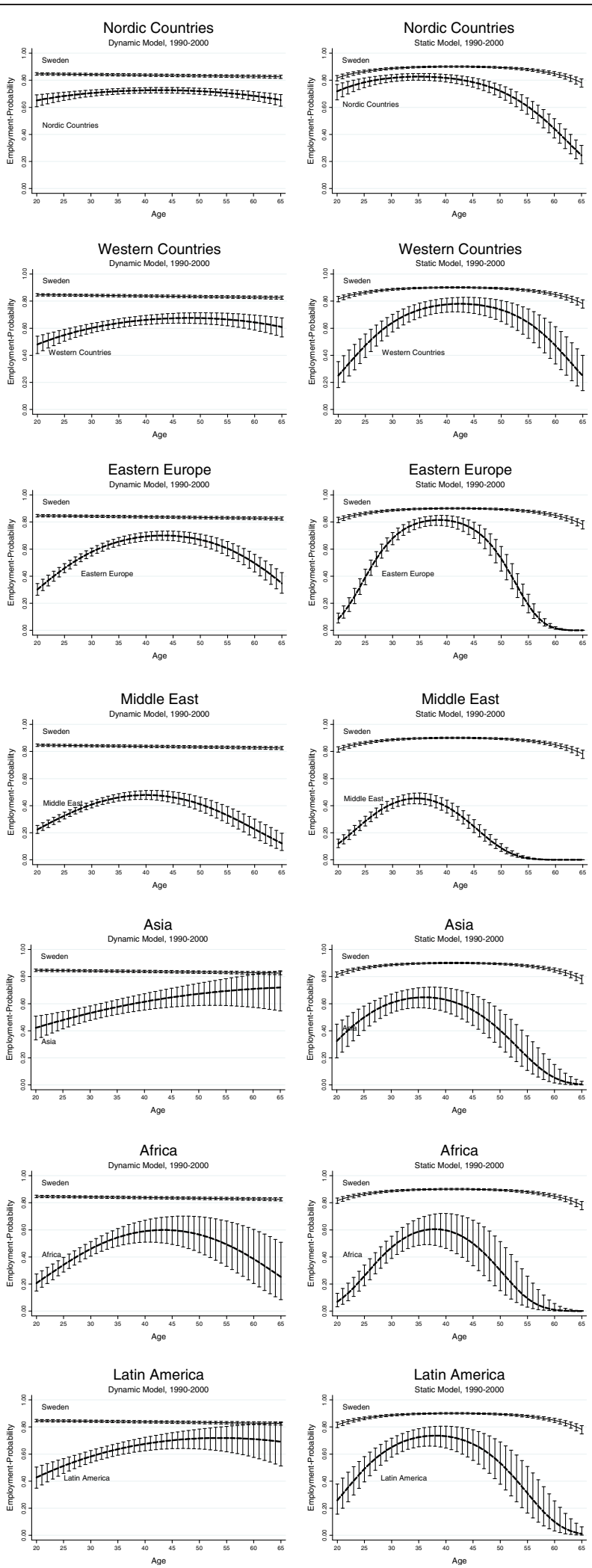

Fig. 1 Age-employment-probability profiles of immigrants and natives by region of origin and model. The vertical lines are the average $95 \%$ confidence intervals. See Table 3 for the details of the model specifications 
of the static and the dynamic model are almost opposite for Asians and Latin Americans. For instance, the static model predicts a very low (lower than 0.25) probability of being employed for Asian immigrants around age 50 (the probability is very close to zero around 60 ). Yet, the dynamic model suggests a full assimilation that is statistically significant at the conventional levels.

\subsection{Human capital and assimilation in the static and the dynamic model}

Previous results suggest that the static model overstates the speed of assimilation in the early years while it also predicts that the human capital depreciates quickly compared with what is predicted by the dynamic model. In this section, we focus on the persistence of the employment status and resulting assimilation outcome of immigrants by educational attainment levels to understand the role of human capital in the difference between the static and the dynamic assimilation model. The model specifications given in (1-3) and (4-6) are estimated by splitting the data into three educational categories: primary education (9 years of education), secondary education (high school diploma and more than 9 years but fewer than 12 years of education), and university degree or more (education more than high school). ${ }^{11}$ We report the average marginal effects of the structural state dependence experienced at different educational attainment levels in Table 5.

The results reveal that, for immigrants, educational attainment levels do not substantially correlate with employment status persistence. Yet, the situation for native Swedes looks very different in this respect. University-educated native Swedes display almost the same structural state dependence as university-educated immigrants (even lower in some cases, especially compared with immigrants from Western countries, Eastern Europe, and Latin America). This result implies that the previous findings are mainly driven by natives and immigrants with primary and secondary education, as they exhibit significantly different magnitudes of state dependence.

We have also calculated the initial employment probability difference and the development of the relative probability over time for each education group, yet we do not report them here. ${ }^{12}$ First, we note that there is full assimilation only among some groups of immigrants. University-educated Nordics (in 11-15 years) and Westerners (in 21-25 years) as well as Eastern Europeans with secondary school (in 16-20 years) are predicted to be fully assimilated according to the static model. Yet, just after full assimilation, the employment probabilities of immigrants unrealistically diverge away from those of natives (see, e.g., Nordic, Western, Eastern European, and Latin American immigrants with secondary education). The dynamic model suggests a slow yet steady growth in employment probabilities, and once achieved, the probability level stays stable and gradually falls later. A higher structural state dependence implies a flatter life cycle employment probability profile, which is systematically observed among the lower educated immigrants as their employment status is less interrupted than that of university-educated immigrants.

\section{Conclusions}

Immigrants' economic integration has been predominantly studied in a static framework. One consistent finding in the literature is that the immigrant's employment 
Table 5 Structural state dependence on the employment probabilities of immigrants and natives by education

\begin{tabular}{|c|c|c|c|c|c|c|c|c|}
\hline \multirow[b]{2}{*}{ Lagged employment status $(\lambda)$} & \multicolumn{8}{|l|}{ Regions of origin } \\
\hline & Nordic countries & Western countries & Eastern Europe & Middle East & Asia & Africa & Latin America & Native Swedes \\
\hline University & $0.481^{* * *}(0.019)$ & $0.570^{* * *}(0.014)$ & $0.607^{* * *}(0.009)$ & $0.505^{* * *}(0.012)$ & $0.426^{* * *}(0.039)$ & $0.496^{*}(0.268)$ & $0.591^{* * *}(0.032)$ & $0.504^{* * *}(0.015)$ \\
\hline Secondary & $0.501^{* * *}(0.010)$ & $0.550^{* * *}(0.011)$ & $0.600^{* * *}(0.007)$ & $0.457^{* * *}(0.007)$ & $0.545^{* * *}(0.014)$ & $0.535^{* * *}(0.014)$ & $0.535^{* * *}(0.016)$ & $0.810^{* * *}(0.004)$ \\
\hline Primary & $0.503^{* * *}(0.012)$ & $0.485^{* * *}(0.018)$ & $0.478^{* * *}(0.017)$ & $0.439^{* * *}(0.010)$ & $0.551^{* * *}(0.019)$ & $0.538^{* * *}(0.020)$ & $0.533^{* * *}(0.019)$ & $0.829^{* * *}(0.005)$ \\
\hline
\end{tabular}

Note: We estimate the models in different specifications. Robust standard errors are reported in parentheses. See also Table 3 for the details and the variables used in the model specification

$* * * * *$, and $*$ indicate significance levels at 1,5 , and $10 \%$, respectively 
probabilities show high growth after arrival but then diverge very quickly. Using a highquality register-based panel dataset collected among immigrants in Sweden, we compare the standard static model with the dynamic assimilation model in which the differential past employment experience of natives and immigrants is taken into account. The assimilation model that we offer controls for structural state dependence, which captures the effect of past employment experiences and the resulting human capital accumulation on current and future employment probabilities. To this end, we estimate state-of-the-art models based on non-linear static and dynamic random-effects probit models in which the initial conditions are considered to be endogenous.

The main conclusions of this paper can be summarized as follows: First, we confirm the previous results in the literature, particularly regarding the low degree of assimilation among migrants in the Swedish labor market. This static model suggests a large initial employment probability disadvantage. The model predicts large marginal assimilation rates in the initial years after arrival, but also indicates fast and high depreciation of human capital later, thus predicting an early and very large "penalty" for the age for immigrants, which is highly unrealistic. Second, we find substantial state dependence on the employment probabilities, which differs between natives and immigrants. The results of the dynamic assimilation model are striking, and the predictions fit to the data very well. The dynamic model predicts a $10-15$ percentage points lower initial employment probability disadvantage and a slow but steady growth in employment probabilities during the initial years after arrival. Total years of positive marginal assimilation rates are estimated to be 10-15 years longer compared with the static model. According to the dynamic model, immigrants are able to keep their positive marginal rate of assimilation for a longer time since the actual past experience and resulting human capital are correctly transferred to the older ages. Third, the analysis based on educational attainment levels also suggests that university-educated immigrants experience very similar structural state dependence as native Swedes. However, having primary and secondary education is associated with very low employment transitions, leading to a very high level of dependence on employment status for natives compared with immigrants.

To our knowledge, this paper is the first in the migration literature to investigate the dynamics of assimilation and to point out that the static model is not sufficient to predict realistic assimilation outcomes of immigrants. The important message given by the state-of-the-art dynamic model estimated in this paper is that there is a slow yet steady assimilation process among the immigrants in Sweden and their relative employment probabilities do not diverge unrealistically as the static model suggests. The immigrants from Western and Nordic countries are successful. Another three migrant groups that are doing well are immigrants from Asia, Latin America, and Eastern Europe. The model offered in this paper suggests that only the Africans and especially those from the Middle East fare worse in the Swedish labor market. With the exception of some migrant groups (e.g., Asians and Latin Americans), we do not find any evidence of full assimilation. Yet, with the exception of African and Middle Eastern immigrants, all immigrant groups are able to reduce the employment probability gap under 10-20 percentage points in the Swedish labor market. 


\section{Endnotes}

${ }^{1}$ In another strand of literature aiming to examine welfare take-up differences between immigrants and natives in Sweden, Hansen and Lofstrom (2009) find that refugee immigrants display a greater degree of structural state dependence than natives and non-refugee immigrants in terms of welfare participation. They conclude that high welfare take-up rates among refugee immigrants may be due to the existence of a "welfare trap."

${ }^{2}$ Note that the lagged dependent variable is assumed as observed (non-latent). The other alternative is to consider that the lagged employment status is also unobserved. Considering the lagged dependent variable as observed or latent leads to different implications in both economic and estimation terms.

${ }^{3}$ The model given in (1) is a static assimilation model with the unobserved individual effects when $\lambda$ is zero. The static model estimated in the present paper uses a similar auxiliary distribution for the unobserved individual effects based on the Chamberlain (1984) approach. The auxiliary distribution of the unobserved individual effects does not include the first-period employment status in the case of the static model.

${ }^{4}$ In a comprehensive Monte Carlo experiment, Akay (2012) reports that the methods perform equally well for durations longer than $5-8$ periods.

${ }^{5}$ Edin et al. (2000) point out that the measures of immigrants' assimilation can be distorted if a significant fraction of immigrants return back to their home country. In this respect, the migrant sample might not be a random sample of the population of immigrants. Klinthäll (2003) finds that $40 \%$ of immigrants from Germany, Greece, Italy, and the USA leave Sweden within 5 years. His main hypothesis, borrowed from the US emigration studies, is that the least successful immigrants leave. However, as pointed out by Arai et al. (2000), even low-earning immigrants might have a strong incentive to stay because of the relatively high living standard in Sweden compared with other countries, even in the lower range of the earnings distribution. In our sample, less than $5 \%$ disappeared from the data during the observation period. It is in our case difficult to model return migration with the data available, since it is not possible to distinguish emigrants from those who died.

${ }^{6}$ This criterion is also adopted in LINDA as the basic amount, which entitles someone to the earnings-public pension system.

${ }^{7} \mathrm{We}$ also generate alternative arrival cohort intervals to test the sensitivity of the results. The main results presented in this paper are not affected.

${ }^{8}$ Local unemployment rates are calculated as follows: We first collect data from registers on the total number of individuals living in a municipality split by gender, age, and employed in a year. We then calculate the unemployment rate by dividing the number of unemployed by the population in the municipality of residence, by age and gender for each year.

${ }^{9}$ The results for the other parameters are in line with the literature: The employment probabilities increase with age at a decreasing rate, and educational attainment level increases the probability of employment. Estimation results are not reported here due to space limitations, but they can be provided upon request.

${ }^{10} \mathrm{We}$ also interact with the structural state dependence parameter with age and yearsince-migration (and squared terms) to allow for differential impact of state dependence across the life cycle. The results are practically the same. The results are also 
stable for the exclusion of local unemployment rates. We also try an alternative specification of the auxiliary distribution used as a part of the initial values problem by using the combinations of the variables. The life cycle pattern generated by the dynamic model is highly stable.

${ }^{11}$ Another weakness of the register data is that the country in which the education is acquired is not available. Therefore, the results do not account for the differences in educational quality for those immigrants who were educated partially or fully in their home country.

${ }^{12}$ Relative employment probabilities and life cycle employment probability profiles by education categories and immigrants' regions of origin can be provided upon request.

\section{Competing interests}

The IZA Journal of Migration is committed to the IZA Guiding Principles of Research Integrity. The author declares that he has observed these principles.

\section{Acknowledgements}

I would like to thank the anonymous referee and the editor for the useful remarks.

Responsible editor: Denis Fougère

\section{Author details}

${ }^{1}$ University of Gothenburg, Vasagatan 1, Box 640, 40530 Gothenburg, Sweden. ${ }^{2}$ IZA, Bonn, Germany. ${ }^{3}$ LISER, Belval, Luxembourg.

Received: 14 September 2015 Accepted: 4 April 2016

Published online: 12 July 2016

\section{References}

Aguilar R, Gustafsson B. The earnings assimilation of immigrants. Labour. 1991;5:37-58.

Akay A. Finite-sample comparison of alternative methods for estimating dynamic panel data models. J Appl Econ. 2012; 27:1189-204.

Antelius J, Björklund A. How reliable are register data for studies of the return on schooling? An examination of Swedish data. Scand J Educ Res. 2000;44:341-55.

Arai M, Schröder L, Vilhelmsson R. En svartvit arbetsmarknad. Report to the Expert Group in Public Economics (ESO), DS 2000; 2000. p. 47. http://eso.expertgrupp.se/rapporter/en-svartvit-arbetsmarknad-en-eso-rapport-om-vagen-franskola-tillarbete/.

Arulampalam W, Stewart M. Simplified implementation of then Heckman estimator of the dynamic probit model and a comparison with alternative estimators. Oxf Bull Econ Stat. 2009;71:659-81.

Åslund O, Rooth D-O. Do when and where matter? Initial labour market conditions and immigrants earnings. Econ J. 2007;117:422-48

Baker M, Benjamin D. The performance of immigrants in the Canadian labor market. J Labor Econ. 1994;12:369-405.

Barth E, Bratsberg B, Raaum O. Identifying earnings assimilation of immigrants under changing macroeconomic conditions. Scand J Econ. 2004;106:1-22.

Bauer T, Lofstrom M, Zimmermann KF. Immigration policy, assimilation of immigrants and natives' sentiments towards immigrants: evidence from 12 OECD countries. Swedish Economic Policy Review. 2000;7:11-53.

Bell BD. The performance of immigrants in the United Kingdom: evidence from the GHS. Economic Journal. 1997;107: 333-44.

Bevelander P. Labour force participation of immigrants in Sweden 1960-1990. Lund, Sweden: Dept. of Economic History; 1995. Fil. Lic-dissertation.

Bevelander P. The employment status of immigrant women: the case of Sweden. Int Migr Rev. 2005;39:173-202.

Bevelander P, Nielsen HS. Declining employment success of immigrant males in Sweden. Observed or unobserved characteristics? J Popul Econ. 2001;14:455-71.

Borjas GJ. Assimilation, changes in cohort quality, and the earnings of immigrants. J Labor Econ. 1985;3:463-89.

Borjas GJ. Self-selection and the earnings of immigrants. Am Econ Rev. 1987;77:531-53.

Borjas GJ. Assimilation and changes in cohort quality revisited: what happened to immigrants earnings in the 1980s? J Labor Econ. 1995;13:201-45.

Borjas GJ. The economic analysis of immigration. In: Ashenfelter OC, Card D, editors. Handbook of labor economics. 3Ath ed. Amsterdam: Elsevier; 1999. p. 1697-760.

Chamberlain G. Panel data. In: Griliches Z, Intriligator MD, editors. Handbook of econometrics. 2nd ed. Amsterdam: North Holland; 1984. p. 1247-320.

Chiswick BR. The effect of Americanization on the earnings of foreign-born men. J Polit Econ. 1978;86:897-921.

Chiswick BR, Cohen Y, Zach T. The labor market status of immigrants: effects of the unemployment rate at arrival and duration of residence. Ind Labor Relat Rev. 1997;50:289-303.

Constant A, Massey DS. Labor market segmentation and the earnings of German guestworkers. Popul Res Policy Rev. 2005;24:489-512.

Duleep HO, Regets MC. Immigrants and human-capital investment. Am Econ Rev. 1999:89:186-91.

Dustmann C. Speaking fluency, writing fluency, and earnings of immigrants. J Popul Econ. 1994;7:133-56. 
Duvender AS. Do country-specific skills lead to improved labor market positions? An analysis of unemployment and labor market returns to education among immigrants in Sweden. Work Occup. 2001;28:210-33.

Edin P-A, Frederiksson P. LINDA: Longitudinal Individual Data for Sweden, Department of Economics, Uppsala University, Working Paper 2000; 2000. p. 19

Edin P-A, LaLonde RJ, Åslund O. Emigration of immigrants and measures of immigrant assimilation: evidence from Sweden. Swedish Economic Policy Review. 2000b;7:163-204.

Ekberg J. Economic progress of immigrants in Sweden from 1970 to 1990: a longitudinal study. Scand J Soc Welf. 1994; 3:148-54.

Friedberg RM. You can't take it with you? Immigrant assimilation and the portability of human capital. J Labor Econ. 2000;18:221-51.

Frijters P, Shields MA, Price SW. Job search methods and their success: a comparison of immigrants and natives in UK. Econ J. 2005;115:359-76.

Gustafsson B, Zheng J. Earnings of immigrants in Sweden, 1978 to 1999. Int Migr. 2006;44:79-117.

Hammarstedt M. Disposable income differences between immigrants and natives in Sweden. Int J Soc Welf. 2001;10: $117-26$.

Hammarstedt M. Income from work among immigrants in Sweden. Rev Income Wealth. 2003;49:185-203.

Hansen J, Lofstrom M. The dynamics of immigrant welfare and labor market behavior. J Popul Econ. 2009;22:941-70.

Hayfron JE. The performance of immigrants in the Norwegian labor market. J Popul Econ. 1998;11:293-303.

Heckman JJ. The incidental parameters problem and the problem of initial conditions in estimating a discrete timediscrete data stochastic process. In: Manski C, McFadden D, editors. Structural analysis of discrete panel data with econometric applications. Cambridge: MIT Press; 1981. p. 179-96.

Husted L, Skyt Nielsen H, Rosholm M, Smith N. Employment and wage assimilation of male first generation immigrants in Denmark. Int J Manpow. 2001;22:39-68.

Hyslop DR. State dependence, serial correlation and heterogeneity in intertemporal labor force participation of married women. Econometrica. 1999;67:1255-94.

Klinthäll M. Return migration from Sweden 1968-1996: a longitudinal analysis. Stockholm: Almqvist \& Wiksell International; 2003.

LaLonde RJ, Topel RH. Immigrants in the American labor market: quality, assimilation, and distributional effects. Am Econ Rev. 1991;81:297-302.

LaLonde RJ, Topel RH. The assimilation of immigrants in the U.S. labor markets, NBER Working Paper No 3573; 1992

Longva P, Raaum O. Unemployment and earnings assimilation of immigrants. Labour. 2002;16:469-89.

Mundlak Y. On the pooling of time series and cross section data. Econometrica. 1978;46:69-85.

Scott K. The immigrant experience: changing employment and income patterns in Sweden, 1970-1993. In: Lund Studies in Economic History (Vol. 9. Lund, Sweden: Lund University Press; 1999.

Wooldridge JM. Simple solutions to the initial conditions problem in dynamic, nonlinear panel data models with unobserved heterogeneity. J Appl Econ. 2005;20:39-54.

\section{Submit your manuscript to a SpringerOpen ${ }^{\circ}$ journal and benefit from:}

- Convenient online submission

- Rigorous peer review

- Immediate publication on acceptance

- Open access: articles freely available online

- High visibility within the field

- Retaining the copyright to your article 